TERMINUS

t. 19 (2017), z. 2 (43), s. 363-385

doi: 10.4467/20843844TE.17.011.8404

www.ejournals.eu/Terminus

Tomasz Górny

Uniwersytet Warszawski, Warszawa

tomaszgoorny@gmail.com

\title{
Rhetorics of Johann Sebastian Bach's \\ Orgelbüchlein: An Introduction with a Case \\ Study of BWV 614
}

Jacques van Oortmerssen (1950-2015)

In memoriam $^{1}$

\begin{abstract}
The paper presents an examination of the interplay of music and lyrics in the Orgelbüchlein by Johann Sebastian Bach that summarises some of the earlier findings in this area and outlines a wider context of the studies concerning the relationship of rhetoric and music. The attention is devoted to the affect theory and the musical
\end{abstract}

1 The dedication of this paper has been occasioned by my cooperation with an outstanding Dutch organist Jacques van Oortmerssen, a teacher of the organ at the Conservatorium van Amsterdam and lecturer at many others colleges (e.g. Oxford University and the Sibelius Academy in Helsinki). Professor Oortmerssen was very enthusiastic about my proposal to devote a year to a joint study of Bach's Orgelbüchlein, which gave rise to the project The interplay of rhetoric and music in the Orgelbüchlein cycle by Johann Sebastian Bach, funded from the grant of the Polish Ministry of Science and Higher Education under the Mobility Plus programme (project number: 1090/MOB/2013/0). The presented paper is the result of this project. 
rhetorical figures theory. Parallels in creating speech and music are discussed as well; this element of musical rhetoric is the least prominent in Orgelbüchlein, but the interpretation of its chorales in terms of inventio, dispositio and elocutio seems legitimate. Finally, a remark is made of the significant influence of the Lutheran tradition, which elevated music, seeing it as a means for the efficient spreading of faith and teaching the Gospel. The paper concludes with a case study of chorale Das alte Jahr vergangen ist BWV 614.

Key words: Johann Sebastian Bach, Orgelbüchlein, rhetoric, musical rhetorical figures theory

\section{The preliminary notes ${ }^{2}$}

The Orgelbüchlein is a collection of 46 organ chorales by Johann Sebastian Bach (BWV 599-644). ${ }^{3}$ According to Russel Stinson most of them were created between 1708 and $1717 .{ }^{4}$ Although Bach planned to compose 164 pieces and prepared a special musical notes' book (his autograph with all 164 cholares' incipits survived $^{5}$ ), he comple-

2 Two parts of this paper (The preliminary notes and The rhetorical function) have been previously published in Polish in my article "Funkcja retoryczna «Orgelbüchlein» Johanna Sebastiana Bacha. Wprowadzenie," Res Rhetorica 4 (2017), pp. 60-74.

3 Additionally, one of the works is unfinished, it can be found in the appendix to the catalogue: O Traurigkeit, o Herzeleid BWV Anh. 200.

4 Some of the pieces from the Orgelbüchlein were composed after 1717 and some probably earlier. R. Stinson, Bach: The Orgelbüchlein, New York \& Oxford 1999 [1996], pp. 12-25. See also dating by Heinz-Harald Löhlein: J.S. Bach, Neue Ausgabe Sämtlicher Werke, Serie IV, Bd. 1, Kritischer Bericht: Orgelbüchlein, Sechs Chöräle von verschiedener Art (Schübler-Choräle), Orgelpartiten, hg. von H.-H. Löhlein, Leipzig 1987, pp. 85-95.

5 The booklet is now part of the collections of the Staatsbibliothek zu Berlin Preußischer Kulturbesitz under the signature Mus. ms. Bach P 283 and is made 
ted only one third of this task. On the title page of the autograph one can read: "Little Organ Book [...] In which a beginner at the organ is given instruction in developing a chorale in many divers ways, and at the same time in acquiring facility in the study of the pedal [...]." Both skills were certainly desired in organists, because preparing musical accompaniment for chorales was seen as their core competence, and because using the pedal section was idiosyncratic for their instrument. ${ }^{7}$ The intention of creating a chorale cycle that would cover the entire liturgical year stems from a rich tradition, following the footsteps of Ammerbach, Scheidt, and Pachelbel. ${ }^{8}$ The phrase "[...] developing a chorale in many divers ways" also hints at Bach's proclivity for developing cycles that explore an issue in $\mathrm{mu}-$

widely available via the Internet website Bach digital (www.bach-digital.de). A facsimile edition of the booklet has also been published in print: J.S. Bach, Orgelbüchlein $B W V$ 599-644. Faksimile der autographen Partitur, hg. von H.-H. Löhlein, Kassel 2010 [1981].

6 "Orgel-Büchlein [...] / Worinne einem anfahenden Organisten / Anleitung gegeben wird, auff allerhand / Arth einen Choral durchzuführen, an- / bey auch sich im Pedal studio zu habi- / litiren, [...]" (title page of the autograph). English translation quoted from: The New Bach Reader: A Life of Johann Sebastian Bach in Letters and Documents, ed. by H.T. David, A. Mendel, C. Wolff, New York \& London 1998, pp. 80-81, no 9 .

7 This phrase might be an oversimplification as it has been known that the organists of Bach's era used clavichord and harpsichord for exercise, both with and without the pedals. It cannot be discounted, therefore, that Bach's students practiced the Orgelbüchlein chorales not only on the organ but also (and maybe primarily) on the pedal clavichord. See R.L. Marshall, "Organ or «Klavier»? Instrumental Prescriptions in the Sources of Bach's Keyboard Works," in: J.S. Bach as Organist: His Instruments, Music, and Performance Practices, ed. by G. Stauffer, E. May, London 1986, pp. 212-239; J. Speerstra, Bach and the Pedal Clavichord: An Organist's Guide, Rochester 2004.

8 An analysis of Bach's pieces (including Orgelbüchlein) in the context of organ chorales tradition can be found in the article of Ernest May: E. May, "The Types, Uses, and Historical Position of Bach's Organ Chorales," in: J.S. Bach as Organist..., pp. 81-101. 
sic and its possible spectrum (e.g. Das Wohltemperierte Klavier). ${ }^{9}$ In Orgelbüchlein, this diversity is reflected in the motives employed, since the work's formal layout is relatively constant and follows three major patterns (with minor exceptions): ${ }^{10}$ the melody chorale, the ornamental chorale, the chorale canon.

A constant in all the Orgelbüchlein pieces is the independent pedal part. Bach emphasizes this in the title page: he composes pieces in a way that would help a beginner organist to master the art of "acquiring facility in the study of the pedal since in the chorales contained therein the pedal is treated as wholly obbligato." ${ }^{11}$ This humble remark is an advertisement of the cycle's pedagogical value but the emancipation of the pedal parts is a significant reimagining of the tradition Bach built on. In the works of Pachelbel and others, the line intended for the pedals was usually relatively simple, whereas in Orgelbüchlein this part was endowed with its own independent voice, the performance of which required considerable skill as well as good hand-and-leg coordination.

9 See K.-J. Sachs, "Die «Anleitung..., auff allerhand Arth einen Choral durchzuführen», als Paradigma der Lehre und der Satzkunst Johann Sebastian Bachs," Archiv für Musikwissenschaft 37, no 2 (1980), pp. 135-154. Sachs has performed a comparative analysis of Orgelbüchlein and Bach's other pedagogical works, especially The Inventions and Das Wohltemperierte Klavier.

${ }_{10}$ The manuscript has limited space for each piece: usually a page, sometimes more. If the work exceeded the predefined size, Bach used tablature notation, which is more economical and can be used in a space where two staves would not fit (e.g. Der Tag, der ist so freudenreich BWV 605, see page 9 of the autograph). This arbitrary decision eliminated longer forms, such as the chorale partita, chorale fantasia (with the exception of In dir ist Freude BWV 615) or chorale motet. See R. Stinson, Bach..., pp. 11-12; S. Hiemke, Johann Sebastian Bach. Orgelbüchlein, Kassel 2007, pp. 11-16.

11 "[...] sich im Pedal studio zu habi- / litiren, indem in solchen darinne / befindlichen Choralen das Pedal / gantz obligat tractiret wird." (title page of the autograph). English translation quoted from: The New Bach Reader..., pp. 80-81, no 69. 
The remarkable role of the pedal parts should also be analysed in terms of Bach's pedagogical methods. Carl Philipp Emanuel Bach wrote that his father taught composition in the following manner:

In the beginning, his students had to master the art of a full 4 -voice basso continuo. He would then proceed to the chorale: he made the bass line for the students and they had to write the alto and tenor parts themselves. Finally, he taught them to write their own bass lines. ${ }^{12}$

A particularly striking feature is the bass line as the key element in the study of composition, both in the four-voice realization of basso continuo and in the harmonization of chorales. Carl Philipp Emanuel Bach's commentary did not concern Orglebüchlein specifically yet it is (at least partially) relevant to that cycle. Stinson contends that in most Bach's melody chorales, the composing started with the soprano (i.e. the chorale melody), followed by the bass (harmonic base) and was then complemented with the alto and tenor lines. ${ }^{13}$ In Bach's epoch, playing the instrument invariably involved improvising and composing, and so the pedagogical function of the obligato pedal part in the Orgelbüchlein pieces should be viewed not only as

12 "Den Anfang musten seine | Schüler mit der Erlernung des reinen 4stimmigen [sic!] Generalbaßes machen. Hernach gieng er mit ihnen an die Choräle; setzte erstlich selbst den $\mathrm{Ba}$ dazu, u. den Alt u. den Tenor musten sie selbst erfinden. Alsdenn lehrte er sie selbst Bäße machen." Quoted from: Bach-Dokumente III. Dokumente zum Nachwirken Johann Sebastian Bachs 1750-1800, hg. von H.-J. Schulze, Leipzig 1972, p. 289, no 803. English translation: Zofia Wąchocka.

${ }_{13}$ An exception from this rule can be found in the chorales In dir ist Freude BWV 615 (Stinson suggests that creating a chorale fantasia requires simultaneous scoring of all voices) and Christum wir sollen loben schon BWV 611 (the chorale part is carried in the alto, which is probably the voice Bach wrote first). With the ornamental chorales, it is rather improbable that the composer would start with a ready-made soprano line - a more likely scenario is that Bach outlined the chorale melody, then proceeded to the bass line and the middle voices, to finally write the soprano line with its embellishments. The chorale canons were probably started with the outline of the canons. See R. Stinson, Bach..., pp. 37-38. 
exercise material for organists wishing to improve their pedal technique but also as an introduction to composition.

\section{The rhetorical function}

The Orgelbüchlein chorales were originally closely linked with their lyrics, which were not preserved in the autograph. This causes some organists to use Bach's incipits in a manner similar to the BWV numbers, i.e. a convenient method of identifying a piece that is otherwise inconsequential to its contents. However the extant documents from Bach's circles overthrow this interpretation. ${ }^{14}$ When applying for the post of the organist in Halle, Johann Gotthilf Ziegler (who was one of Bach's students during his Weimar period) made the following remark in his letter to the town council: "As concerns the playing of chorales, I was instructed by my teacher, Capellmeister Bach, who is still living, not to play the songs merely offhand but according to the sense [Affect] of the words." ${ }^{15}$ Ziegler made a wise decision referring to Bach as the name of the Leipzig cantor was held in high esteem in Halle. From our perspective, however, the letter proves that an aspiring organist was familiar with the rules of chorale setting and, more specifically, with setting to the lyrics.

In light of the importance of the chorale lyrics, it seems all the more intriguing that Bach did not include them in his collection.

14 See P. Williams, The Organ Music of J.S. Bach: III A Background, Cambridge 1989 [1984], pp. 59-60.

15 "Was das Choral Spielen betrifft, so bin von meinem annoch lebenden Lehrmeister dem Herren Capellmeister Bach so unterrichtet worden: daß ich die Lieder nicht nur so oben hin, sondern nach dem Affect der Wortte spiele." Quoted from Bach-Dokumente II. Fremdschriftliche und gedruckte Dokumente zur Lebensgeschichte Johann Sebastian Bachs 1685-1750, hg. von W. Neumann, H.-J. Schulze, Leipzig 1969, p. 423, no 542. English translation quoted from: The New Bach Reader..., p. 336, no 340. 
This must appear baffling to contemporary audiences who are not versed in Protestant culture and are therefore unaware that in Bach's times and social circles, the chorale melodies and the accompanying lyrics would have been commonly known, etched in collective memory and functioning much like Christmas carols do nowadays. When Bach wrote the music for Nun komm, der Heiden Heiland, he did not have to write down the lyrics because his target audience would not only instantly recognize the melody but would also know the lyrics by heart and associate the piece with the relevant period in the liturgical year. This is especially valid in the study of Orgelbüchlein as the cycle pieces are remarkable in the care devoted to conveying the meanings of the words with the musical score. Spitta emphasised this quality in Bach's biography:

A further step towards perfecting this form [organ chorale] was taken by Bach when he made the contrapuntal elements in his music a means of reflecting certain emotional aspects of the words. Pachelbel had not attempted this; he lacked the fervid feeling which would have enabled him thus to enter into his subject. ${ }^{16}$

Spitta notes the significant role of the literary side of Orgelbüchlein and the resulting shift in the tradition of organ chorale scoring that Johann Sebastian Bach grew up in. He also adds that the relationship of text and music in Bach's pieces becomes more sophisticated over time and is reflected in Bach's use of specific musical figures for specific phrases. Nevertheless, Spitta stipulates that searching for deeper meaning in each musical phrase might be far-fetched, suggesting in-

16 "Einen weiteren Schritt zur Vervollkommnung der Form that Bach, indem er gewisse Bewegungsvorstellungen der Dichtung in den contrapunctirenden Tonreihen abspiegelte. Pachelbel hatte sich dessen enthalten, ihm fehlte die Innigkeit, sich dergestalt in seinen Gegenstand zu versenken." Ph. Spitta, Joh. Seb. Bach, Leipzig 1916 [1873], Bd. 1, p. 592. English translation quoted from: Ph. Spitta, Johann Sebastian Bach: His Work and Influence on the Music of Germany, 16851750, transl. by C. Bell, J.A. Fuller Maitland, London 1899 [1884], vol. 1, p. 602. 
stead that Bach's purpose was to form a general, overarching musical idea that stems from the same source that shaped the lyrics.

Albert Schweitzer has a similar understanding of the issue but he goes a step further and notes the deep analogies between language and music. In his widely known monograph on Bach, he has distinguished several repetitive motives that form Bach's 'musical vocabulary' Presented below are items of that vocabulary as exemplified in Orgelbüchlein: ${ }^{17}$

1) the 'steps' motives: can express (a) calm and confident faith in God, e.g. the bass passage in Wir Christenleut BWV 612, or, conversely, (b) uncertainty and unsteadiness, e.g. the syncopated bass line in Herr Gott, nun schleuss den Himmel auf BWV 617;

2) the motives of 'beatific peace': can be an expression of joy bordering not so much on ecstasy as inner calm, e.g. the primary motive in Jesu, meine Freude BWV 610;

3) the motives of 'grief': can express (a) a noble complaint, e.g. the groups of semiquavers tied in twos in O Lamm Gottes, unschuldig BWV 618, or (b) dramatic content, e.g. the chromatic passages in Christus, der uns selig macht BWV 620;

4) the motives of 'joy': these (a) reflect happiness using scale passages of semiquavers/quavers, e.g. Erstanden ist der heil'ge Christ BWV 628, or (b) they use variants of a rhythmical group of one quaver and two semiquavers, e.g. one semiquaver and two demisemiquavers, as seen in Mit Fried und Freud ich fahr dahin BWV 616.

Although the motives Schweitzer analyses are both characteristic and repetitive enough to be considered 'lexical' (they also appear

17 A. Schweitzer, J.S. Bach, transl. by E. Newman, New York 1966, vol. 2, pp. 56-74 (the German original was published in Leipzig in 1908 under the title Johann Sebastian Bach and was an extended edition of an earlier French-language publication of 1905, which had a rather telling subtitle that was removed from later editions: J.S. Bach. Le musicien-poète). 
in Bach's cantatas), it must be remembered that the defined group does not always relate to the meaning presented above. Within their contexts (lyrical but also liturgical, theological and other), these motives are vehicles for a more or less defined metaphors, which is why uncritical and literal adoption of Schweitzer's interpretations might lead to ludicrous interpretations.

However, the importance of the lyrical aspect in Bach's works is unquestionable and should be taken into account when analysing the Orgelbüchlein chorales. The interplay of the sound and language in the cycle is a vast subject that has been studied by scholars of rhetorics and music. This research area covers several complex issues that in my view do not form a coherent system - instead, there are several different schools and traditions, including:

a) Affect theory: Originally, this theory relied on the ancient concept of ethos. However, its Baroque continuation was inspired chiefly by Descartes' mechanistic physiology, which assumed that a sound is an external element that can exert a rational and repetitive influence on human affects to evoke an emotional response. Athanasius Kircher, a major theoretician of affects in music, maintained that dissonant intervals slow down life processes and hence induce sadness, whereas consonance intervals have the opposite effect. In his theory, which he called musica pathetica, a special role was assigned to the minor second, which Kircher considered 'the soul of all music'.18 ${ }^{18}$ Following the theory of affects, emotional qualities were assigned not just to the intervals but to whole musical scales, the most widely known example of which can be found

18 "Totius musicae anima semitonium est." Quoted from the facsimile edition: A. Kircher, Musurgia universalis sive ars magna consoni et dissoni, hg. von U. Scharlau, Hildesheim 1999 [1650], vol. 1, p. 554 (the quoted passage can be found on page 620 , which is most likely a printing error as the previous page is numbered 553). 
in a treatise by Johann Mattheson entitled Das neu-eröffnete Orchestre. ${ }^{19}$

b) The theory of rhetorical figures: This concept adapted some set formulas used in speech (i.e. rhetorical figures) for use in music to achieve the desired effect. The tradition dates back to the Renaissance, or even to medieval art, but only gained prominence in shaping the musical language in the Baroque era. ${ }^{20}$ Many musical rhetorical figures were developed in the $17^{\text {th }}$ and $18^{\text {th }}$ centuries: some of them follow the same rules as their linguistic counterparts, e.g. aposiopesis, or falling silent, whose expressive value consists in the unexpected and abrupt pause in the narration; some use autonomous solutions that are typical only for groups of sounds, e.g. saltus duriusculus, ${ }^{21}$ or a shift by a dissonant interval, whose usual function is to emphasise a single word of grave importance - in Bach's cantatas, it is frequently used for the word Tod, 'death' (BWV 4, BWV 21 and others).

c) The proximity of the linguistic and musical paradigms has also resulted in viewing composition as analogous to speech pro-

19 J. Mattheson, Das neu-eröffnete Orchestre, Hamburg 1713, pp. 231-253.

${ }^{20}$ Musical rhetorical figures have been a part of contemporary musical studies since early $20^{\text {th }}$ century. The concept was introduced in the groundbreaking works of Arnold Schering ("Die Lehre von den musikalischen Figuren im 17. und 18. Jahrhundert," Kirchenmusikalisches Jahrbuch 21 (1908), pp. 106-114) and his followers (e.g. H.-H. Unger, Die Beziehungen zwischen Musik und Rhetorik im 16.-18. Jahrhundert, Hildesheim 1985 [1941]). The more recent works on this theory include: D. Bartel, Handbuch der musikalischen Figurenlehre, Laaber 1985; J. Tarling, The Weapons of Rhetoric: A Guide for Musicians and Audiences, St. Albans 2004. However, also worth noting are the critical voices on the possibility and historical legitimacy of using musical rhetorical figures as a reference framework (see e.g. A. Forchert, "Musik und Rhetoric im Barock," Schütz-Jahrbuch 7/8 (1985/1986), pp. 5-21; J. Klassen, "Musica Poetica und musikalische Figurenlehre - ein produktives Missverständnis," Jahrbuch des Staatlichen Instituts für Musikforschung Preußischer Kulturbesitz (2001), pp. 73-83).

21 See D. Bartel, Handbuch..., pp. 250-251. 
duction. Not only was the general purpose of a musical piece defined in terms of three basic tenets of rhetoric (movere, 'to move,' docere, 'to teach,' and delectare, 'to delight') but also the model of an oration was adopted, in which the orator begins their speech with stating the subject (inventio), then arranges their points in a relevant order (dispositio), proceeds to setting the relevant style (elocutio), to finally memorise the speech (memoria) and deliver it (pronuntiatio). ${ }^{22}$ The principles for the arrangement of a speech elements (dispositio) were sometimes used as a model for musical pieces. Scholars often quote the scheme presented in Johann Mattheson's treatise Der vollkommene Capellmeister. This Hamburg musician and theoretician wrote in the second part of his voluminous work that the consequence of the subsequent parts in a wellcomposed melody shows similarity to the rhetorical dispositio and thus is composed of the following parts: exordium (introduction), narratio (presenting the subject or main theme; in music, e.g. the vocal part after instrumental prelude), propositio (developing the idea; in music, this is done e.g. by variations), confutatio (presenting, and thus neutralising, counter arguments; in music, this is e.g. presenting the theme in a chromatic version), confirmatio (returning to the main idea and confirming its truth; in music, it is e.g. reprising the main theme) and peroratio (ending). ${ }^{23}$ This concept should not, however, be generalised: firstly, it was relatively exceptional, and secondly, Mattheson's work signalled the need for reflection on the composition rather than presented a universal model. This is evidenced by the fact that within just two pages, two different versions of this concept can be found: in

22 See B. Wilson, G.J. Buelow, P.A. Hoyt, "Rhetoric and Music," in: The New Grove Dictionary of Music and Musicians, ed. by S. Sadie, London \& New York 2001, vol. 21, pp. 260-275.

23 J. Mattheson, Der vollkommene Capellmeister, Hamburg 1739, p. 236. 
page 235, confutatio is preceded by confirmatio, whereas on the next page, where Mattheson explains the terms used, the order is reversed (confirmatio follows confutatio). In the author's own words: “Thus, even though the parts named do not always appear in this order, or follow one another, they can be found in nearly all well-turned melodies." ${ }^{24}$

Orgelbüchlein does not show any clear traces of this inspiration yet one can speculate that certain themes corresponding with their lyrics can be interpreted as inventio, the layout of the parts (soprano, alt, tenor, bass) as dispositio and the embellishment of the melody in ornamental chorales as meticulous polishing of the elements of style, i.e. elocutio.

d) Last but not least: the liturgical function and the Protestant Lutheran context cannot be discounted in the discussion of rhetoric and Orgelbüchlein. Bach worked on the melodic lines sung by Protestant community at that time, but it is not known if those pieces were performed together with worshippers' singing, or used only as an introduction, or included in between respective stanzas. ${ }^{25}$ In the Lutheran tradition, music was second only to Gospel in its importance as a tool for instruction in faith. Scholars see this highly influential position of music as the origin of the Baroque musical rhetoric that was (consciously and purposefully) shaped primarily in the countries with predominantly Protestant Lutheran population (John Calvin, on the other hand, was strongly opposed

24 "Denn, obgleich die erwehnten Stücke sich eben nicht allemahl in derselben Reihe befinden oder auf einander folgen sollten; so werden sie doch in guten Melodien fast alle anzutreffen seyn." Quoted from: ibidem, p. 237. English translation by Zofia Wąchocka.

25 P. Williams, The Organ Music of J.S. Bach: III A Background, pp. 20-32. 
to all music). ${ }^{26}$ Dietrich Bartel ${ }^{27}$ also notices that in Lutheran schools, Latin, rhetoric and music was often taught by the same teacher (usually the cantor), which naturally led to what we would nowadays call an interdisciplinary approach. ${ }^{28}$

There are clear attempts in Orgelbüchlein at tailoring the affective force of the music to the lyrics. In many pieces, the general ambience of Bach's chorales is tied to the literary aspect (e.g. the unusually joyful chorale In dir ist Freude BWV 615, or the opposite, sorrowful O Lamm Gottes, unschuldig BWV 618, inspired by the Passion of Christ). Some pieces also contain characteristic melodious or melodious-harmonic figures that put an emphasis on a specific word or phrase (e.g. in the chorale Durch Adams Fall ist ganz verderbt BWV 637, the bass part has a number of repeated leaps by a seventh, which scholars have agreed is a representation of Adam's fall; in Vom Himmel kam der Engel Schar BWV 607, the rising and falling melody lines are a reflection of the descending and ascending angels that are the subject of the chorale's lyrics).

This phenomenon was first observed by Spitta and Schweitzer but it was only with more in-depth studies of the ties of music and rhetoric that these observations could be analysed within a larger framework of the affect theory and rhetorical figures theory. ${ }^{29}$ Whether

26 K. Korpanty, "Zagadnienie tekstu słownego i jego muzyczna interpretacja w ujęciu niemieckich teoretyków muzyki epoki baroku," Muzyka 224, no 1 (2012), pp. 53-72.

27 D. Bartel, "Rhetoric in German Baroque Music: Ethical Gestures," The Musical Times 144, no 1885 (2003), pp. 15-19.

28 A notable example of this is Joachim Burmeister, a Rostock cantor and teacher at the local school, who introduced the concept of close ties of music and rhetoric in his treatises. See B.V. Rivera, M. Ruhnke, "Burmeister Joachim," in: The New Grove Dictionary..., vol. 4, pp. 635-637.

29 The issues of rhetorical influences on Bach's organ music have been discussed e.g. by J. Kloppers, Die Interpretation und Wiedergabe der Orgelwerke Bachs. Ein Beitrag zur Bestimmung von stilgerechten Prinzipien, Frankfurt am Main 1965; P. Williams, The Organ Music of J.S. Bach: III A Background, pp. 65-91; V.P. Benitez, "Musical-Rhetorical Figures in the "Orgelbüchlein» of J.S. Bach," Bach: Journal of 
Bach consciously used any of these theories remains speculative. He was certainly familiar with some of them: as a school boy in Lüneburg, he had to master the principles of classical rhetoric and his close friend, Johann Gottfried Walther, made use of the concept of musical rhetorical figures in his composition textbook Praecepta der musicalischen Composition, ${ }^{30}$ completed in 1708 (which is when Bach stayed in Weimar and started working on the Orgelbüchlein). In the next part of this paper, an analysis of the rhetorical function of the chorale Das alte Jahr vergangen ist BWV 614 will be made.

\section{A case study: Das alte Jahr vergangen ist BWV 614}

The creator of both lyrics and chorale melody of Das alte Jahr vergangen ist was Johann Steuerlein. Wilhelm Thomas contends that a fragment of this piece was current already in 1568 but the whole work was only published in Steuerlein's Neuen geistlichen Gesängen in $1588 .{ }^{31}$ Bach scored the melody in question four times: as an ornamental chorale (BWV 614), a melodic chorale (BWV 1091), and twice as a simple four-part piece (BWV 288 and BWV 289). Between 1784 and 1787, a four-volume collection of Johann Sebastian Bach's chorale scores was published, edited by his son Carl Philipp Emanuel and his student Johann Philipp Kirnberger. The publication contains two versions of Das alte Jahr vergangen ist: it can be found in Volume 2 (BWV 288) and in Volume 4 (BWV 289). BWV 288 is scored in the same key as the Orgelbüchlein piece, which makes it a good benchmark for our analysis:

the Riemenschneider Bach Institute 18 (1987), pp. 3-21; S. Hiemke, Johann Sebastian Bach..., pp. 80-89.

30 See J.G. Walther, Praecepta der musicalischen Composition, hg. von P. Benary, Leipzig 1955.

31 W. Thomas, "Zu Weisen und Texten," in: J.S. Bach, Choralsätze zum Orgelbüchlein, hg. von H. Keller, Kassel 1969 [no pagination]. 
162. Das alte Jafk vergangen ift.

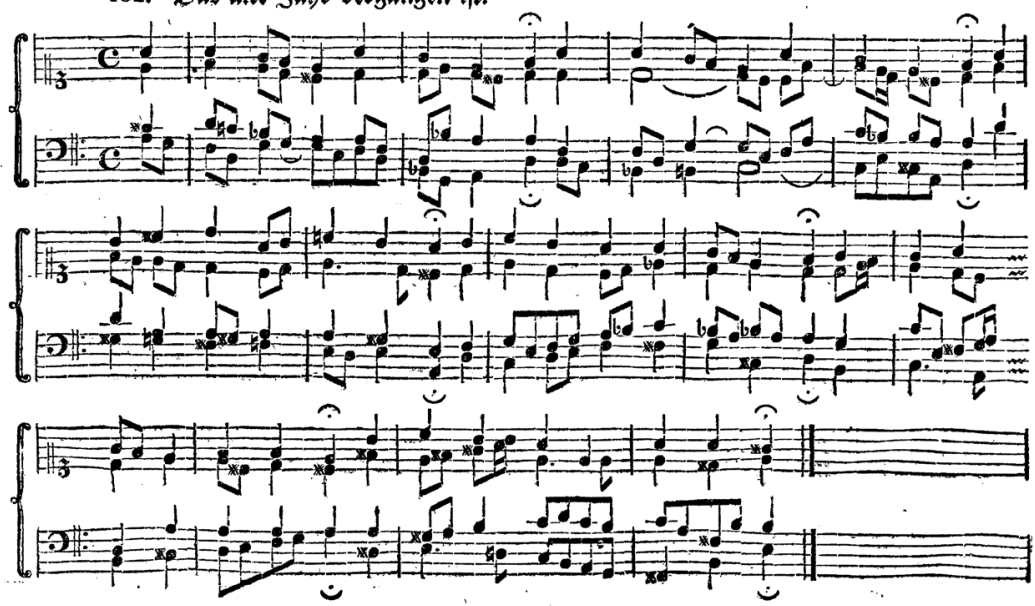

1. J.S. Bach, Das alte Jahr vergangen ist BWV 288, in: idem, Vierstimmige Choralgesänge, Bd. 2, Leipzig 1785, p. 92, no 162
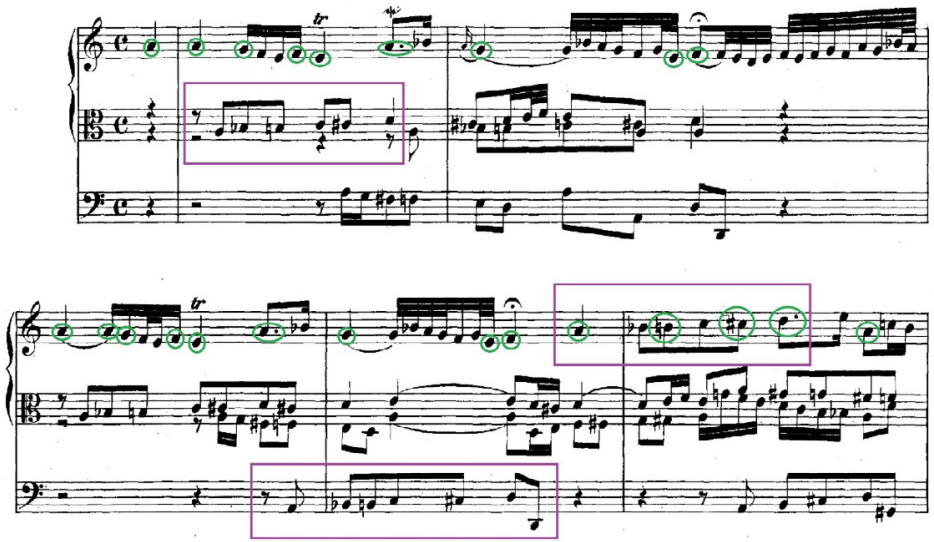

2. J.S. Bach, Das alte Jahr vergangen ist BWV 614, in: idem, Orgel-Büchlein, Bach-Gesellschaft Ausgabe, Bd. 25, hg. von W. Rust, Leipzig 1878, p. 19 [highlights mine - T.G.] 
The chorale melody (highlighted) is constantly present but Bach filled the spaces between sounds with rich embellishments. This is typical for an ornamental chorale and is closely related to the performance practice. It lends the soprano part a distinctly soloist quality, which is why it is commonly played on a separate manual (in northern Germany, it was usually Rückpositiv, whereas in Thüringen Brustwerk or Oberwerk would be used ${ }^{32}$ ), with a registration that brings out its function. The alto and tenor parts are performed on another manual, with decidedly less dominant registration; the piece is completed by the obligato bass part in the pedals. This configuration of parts was suggested quite clearly by the composer's annotation: "à 2 Clav. et Ped." ("for two manuals and a pedal").

The piece starts, somewhat unusually, with a repeated $a^{1}$ sound in a soprano solo. ${ }^{33}$ In the next bars, the part is sumptuously embellished, with perhaps the most interesting ornament being the figure found immediately after the second fermata (bars 4 and 5 , framed). The passage that originates in the chorale melody, i.e. $\mathrm{a}^{1}-$ $b^{1}-c$-sharp ${ }^{2}-d^{2}$, has been broken into two with $b$-flat ${ }^{1}$ and $c^{2}$, which results in a chromatic passage of $a^{1}-b-f l a t^{1}-b^{1}-c^{2}-c-s h a r p^{2}-d^{2}$. This motif stems directly from the embellishment principle of the chorale melody but it has been used on a far wider scale. Bach also makes use of it in other parts (selected passages have been framed), both in the primary version and in its modification, thanks to which it functions as the foundation of the whole piece. In rhetorical terms, a structure like this could be called passus duriusculus. ${ }^{34}$ Bach himself was probably unfamiliar with this name, introduced by Christoph Bernhard, but he nevertheless knew and used the figure multiple times. In his vocal music, passus duriusculus commonly accompanies words as-

32 See R. Stinson, Bach..., p. 72.

33 As noted by Pieter Williams, Bach would also use this solution later in the Vater unser im Himmelreich in the $3^{\text {rd }}$ part of the Clavier Übung (identically in BWV 683 and slightly modified in BWV 682). P. Williams, The Organ Music of J.S. Bach, vol. 1-2, Cambridge 2008 [ $1^{\text {st }}$ ed.: 1980, $2^{\text {nd }}$ ed., revised: 2003], p. 265.

34 D. Bartel, Handbuch..., pp. 222-223. 
sociated with sin and suffering. ${ }^{35}$ Given the above considerations, an interpretation has been commonly accepted that the chromatic passage that surfaces throughout the entire piece expresses the longing of someone who looks back on the past with melancholy (Schweitzer even classifies it as a 'grief' motive ${ }^{36}$ ). However, Herman Keller $^{37}$ has noted that the score of the piece is more dramatic than its lyrics (cf. Appendix): the music is admittedly a reflection on transience but the text evokes an air of trust and the speaker addresses God with gratitude ("wir dancken dir Herr Jesu Christ / daß du uns in so grosser Gafahr / so gnädiglich behüt diß Jahr;" "Zu dancken und zu preisen dich, / mit allen Engeln ewiglich") and pleas ("Und bitten dich ewigen Sohn;" "Entzeuch uns nicht dein heilsam Wort;" "behüt uns Herr und steh uns bey"). The relationship between what is no more (the old year) and what is to come (the new year) is characterised by the speaker's entrusting their fate to Divine Providence, whereas the piece's musical layer gives it a new dimension. Using the chromatic motif sourced from chorale melody and the unusual harmonies, Bach creates immense emotional tension, which can lead the audience to believe that they are witnessing a dramatic conflict of two worlds, even though it is presented as an intimate ornamental chorale. This solution is suited to the liturgical context of the piece (the feast of New Year ${ }^{38}$ ) and it does not seem far-fetched to assume

35 S. Hiemke, Johann Sebastian Bach..., pp. 127-129.

36 A. Schweitzer, J.S. Bach, p. 65.

37 H. Keller, Die Orgelwerke Bachs. Ein Beitrag zu ihrer Geschichte, Form, Deutung und Wiedergabe, Leipzig [1948], p. 156.

38 The New Year context for this Bach piece has given rise to yet another interpretation. Kees van Houten (Van taal tot klank. Symbolen en achtergronden in de koraalbewerkingen van het Orgel-Büchlein van J.S. Bach, Boxtel 1991, pp. 40-43) has noted that BWV 614 has twelve bars, which can be associated with the twelve months, and the chromatic passage of $a^{1}-b-f l a t^{1}-b^{1}-c^{2}-$ c-sharp $\mathrm{p}^{2}-\mathrm{d}^{2}$, used as a primary version and then inverted, represents the two halves of the year ( 2 × 6 months). To corroborate this reading, van Houten cites the chorale Helft mir Gotts Güte preisen BWV 613, which immediately precedes Das alte Jahr vergangen ist BWV 614 in the Orgelbüchlein autograph. 
that, rather than blindly follow the literal meaning of the text and 'paint' it, Bach considered the context and interpreted the lyrics with the music in a new and profound way.

The 'transitory' quality of the Bach chorale has been captured perfectly in the 1975 Andrei Tarkovsky film Zerkalo (The Mirror). It's a non-linear, dreamlike story of the past and the future, family relations (especially those of the protagonist and his mother and father) as well as social ties (the backdrop of USSR history), where flashbacks from the protagonist's childhood are intertwined with images of the present, the ravages of war accompany almost contemporary narratives, and black-and-white short documentaries are juxtaposed with contemporary frames in full colour. The film begins with a scene of a young boy being hypnotised, which makes him overcome his stammer and start speaking fluently - the rest of the work can be seen as the consequence and the result of his newly regained ability. This new ease of speech enables the protagonist to convey (or create) his story, in which here and now is a compilation of what once was and what is yet to come. In the soundtrack of the movie, the transition between the hypnotic séance and the rest of the tale is presented to the tunes

In the eleventh bar of BWV 613, the soprano melody corresponds to the lyrics (cf. Appendix) about the end of the year ("da sich das Jahr tut enden"), while the alto part has a 6-note passus duriusculus, which is structured identically as in BWV 614 (K. van Houten, Van taal tot klank..., pp. 38-39; see also S. Hiemke, Johann Sebastian Bach..., pp. 128-130). Since BWV 613 was included in the manuscript in the Leipzig period, this has been interpreted as Bach pointing to the six sounds underscoring the word Jahr, 'year.' As tempting as this interpretation is, it glosses over several important facts. Passus duriusculus also features in BWV 613 in passages that cannot be associated with the word Jahr on the literary level: in the $5^{\text {th }}$ bar, the relevant line reads "Mit Gesang und andern Weisen", whereas in the $13^{\text {th }}$ bar, it's "Sonn sich zu uns wenden." The word Jahr also occurs in the lyrics towards the end of the first stanza but in Bach's score, it is not accompanied by passus duriusculus. What is more, the number of bars in BWV 614 was necessitated by the number of bars in pre-existing melody. In light of these facts, I believe there is no clear correlation between the chromatic passage and the word Jahr thus the 'numeral exemplification' hypothesis should be viewed with utmost caution and skepticism. 
of the chorale Das alte Jahr vergangen ist BWV 614, whose emotional gravity perfectly underscores the transitory, ambiguous film space that is charged with expectation of a turning point.

Translated from Polish by Zofia Wąchocka 


\section{Appendix}

\section{Das alte Jahr vergangen ist}

1. Das alte Jahr vergangen ist wir dancken dir Herr Jesu Christ $\mathrm{daß}$ du uns in so grosser Gafahr so gnädiglich behüt diß Jahr.

2. Und bitten dich ewigen Sohn des Vaters in dem höchsten Thron du wollst dein arme Christenheit ferner bewahren allezeit.

3. Entzeuch uns nicht dein heilsam Wort welchs ist der Seelen Trost und Hort fürs Pabstes Lehr und Abgötterey behüt uns Herr und steh uns bey.

4. Hilf daß wir von der Sünd ablahn und fromm zu werden fahen an keinr Sünd im alten Jahr gedenck ein gnadenreich neu Jahr uns schenck.

5. Christlich zu leben seliglich zu sterben und hernach fröhlich am Jüngsten Tag wieder aufzustehn mit dir im Himmel einzugehn.

6. $\mathrm{Zu}$ dancken und zu preisen dich, mit allen Engeln ewiglich O Jesu unsern Glauben mehr zu deines Nahmens Lob und Ehr. ${ }^{39}$
1. The old year now hath pass'd away, We thank Thee, O our God, today, That Thou hast kept us through the year, When danger and distress were near.

2. We pray Thee, O Eternal Son, Who with the Father reign'st as One, To guard and rule Thy Christendom Through all the ages yet to come.

3. Take not Thy saving Word away, Our souls' true comfort and their stay; Abide with us, and keep us free From errors, following only Thee.

4. Oh help us to forsake all sin, A new and holier course begin, Mark not what once was done amiss, A happier, better year be this:

5. Wherein as Christians we may live, Or die in peace that Thou canst give, To rise again when Thou shalt come, And enter Thine eternal home.

6. There shall we thank Thee, and adore, With all the angels evermore; Lord Jesus Christ, increase our faith To praise Thy name through life and death. ${ }^{40}$

40 Quoted from: The Chorale Book for England: A Complete Hymn- 


\section{Helft mir Gottes Güte preisen (first stanza)}

Helft mir Gottes Güte preisen

ihr lieben Kinderlein

mit Gsang und andern Weisen

ihm allzeit danckbar seyn

fürnemlich zu der Zeit

da sich das Jahr thut enden

die Sonn sich zu uns wenden

das neu Jahr ist nicht weit. ${ }^{41}$
Help me to praise God's goodness,

you dear little children,

with songs and other tunes

to be always thankful to him,

especially at the time

when the year comes to an end,

the sun is turned towards us,

the New Year is not distant. ${ }^{42}$
-Book for Public and Private Worship, in Accordance with the Services and Festivals of the Church of England, transl. by C. Winkworth, ed. by W. Sterndale Bennett, O. Goldschmidt, London 1863, no 171 [no pagination].

${ }^{41}$ Quoted from: S. Hiemke, Johann Sebastian Bach..., p. 125.
42 Translated by Francis Browne. Quoted from: http://www.bach-cantatas. com/Texts/Chorale082-Eng3.htm (accessed: 28 Aug 2017). 


\section{Bibliography}

Bach-Dokumente III. Dokumente zum Nachwirken Johann Sebastian Bachs 17501800, hg. von H.-J. Schulze, Leipzig 1972.

Bach-Dokumente II. Fremdschriftliche und gedruckte Dokumente zur Lebensgeschichte Johann Sebastian Bachs 1685-1750, hg. von W. Neumann, H.-J. Schulze, Leipzig 1969.

Bach J.S., Mus. ms. Bach P 283, Staatsbibliothek zu Berlin Preußischer Kulturbesitz.

Bach J.S., Neue Ausgabe Sämtlicher Werke, Serie IV, Bd. 1, Kritischer Bericht: Orgelbüchlein, Sechs Chöräle von verschiedener Art (Schübler-Choräle), Orgelpartiten, hg. von H.-H. Löhlein, Leipzig 1987.

Bach J.S., Orgel-Büchlein, Bach-Gesellschaft Ausgabe, Bd. 25, hg. von W. Rust, Leipzig 1878.

Bach J.S., Orgelbüchlein BWV 599-644. Faksimile der autographen Partitur, hg. von H.-H. Löhlein, Kassel 2010 [1981].

Bach J.S., Vierstimmige Choralgesänge, Bd. 2, Leipzig, 1785.

Bartel D., Handbuch der musikalischen Figurenlehre, Laaber 1985.

Bartel D., "Rhetoric in German Baroque Music: Ethical Gestures," The Musical Times 144, no 1885 (2003), pp. 15-19.

Benitez V.P., "Musical-Rhetorical Figures in the «Orgelbüchlein» of J.S. Bach," Bach: Journal of the Riemenschneider Bach Institute 18 (1987), pp. 3-21.

The Chorale Book for England: A Complete Hymn-Book for Public and Private Worship, in Accordance with the Services and Festivals of the Church of England, transl. by C. Winkworth, ed. by W. Sterndale Bennett, O. Goldschmidt, London 1863.

Forchert A., "Musik und Rhetoric im Barock," Schütz-Jahrbuch 7/8 (1985/1986), pp. 5-21.

Górny T., "Funkcja retoryczna «Orgelbüchlein» Johanna Sebastiana Bacha. Wprowadzenie," Res Rhetorica 4 (2017), pp. 60-74.

Hiemke S., Johann Sebastian Bach. Orgelbüchlein, Kassel 2007.

Houten K. van, Van taal tot klank. Symbolen en achtergronden in de koraalbewerkingen van het Orgel-Büchlein van J.S. Bach, Boxtel 1991.

Keller H., Die Orgelwerke Bachs. Ein Beitrag zu ihrer Geschichte, Form, Deutung und Wiedergabe, Leipzig [1948].

Kircher A., Musurgia universalis sive ars magna consoni et dissoni, hg. von U. Scharlau, Hildesheim 1999 [1650], vol. 1.

Klassen J., "Musica Poetica und musikalische Figurenlehre - ein produktives Missverständnis," Jahrbuch des Staatlichen Instituts für Musikforschung Preußischer Kulturbesitz (2001), pp. 73-83.

Kloppers J., Die Interpretation und Wiedergabe der Orgelwerke Bachs. Ein Beitrag zur Bestimmung von stilgerechten Prinzipien, Frankfurt am Main 1965. 
Korpanty K., "Zagadnienie tekstu słownego i jego muzyczna interpretacja w ujęciu niemieckich teoretyków muzyki epoki baroku," Muzyka 224, no 1 (2012), pp. 53-72.

Marshall R.L., "Organ or «Klavier»"? Instrumental Prescriptions in the Sources of Bach's Keyboard Works," in: J.S. Bach as Organist: His Instruments, Music, and Performance Practices, ed. by G. Stauffer, E. May, London 1986, pp. 212-239.

Mattheson J., Das neu-eröffnete Orchestre, Hamburg 1713.

Mattheson J., Der vollkommene Capellmeister, Hamburg 1739.

May E., "The Types, Uses, and Historical Position of Bach's Organ Chorales," in: J.S. Bach as Organist: His Instruments, Music, and Performance Practices, ed. by G. Stauffer, E. May, London 1986, pp. 81-101.

The New Bach Reader: A Life of Johann Sebastian Bach in Letters and Documents, ed. by H.T. David, A. Mendel, C. Wolff, New York \& London 1998.

Rivera B.V., Ruhnke M., "Burmeister Joachim," in: The New Grove Dictionary of Music and Musicians, ed. by S. Sadie, London \& New York 2001, vol. 4, pp. 635-637.

Sachs K.-J., "Die «Anleitung..., auff allerhand Arth einen Choral durchzuführen», als Paradigma der Lehre und der Satzkunst Johann Sebastian Bachs," Archiv für Musikwissenschaft 37, no 2 (1980), pp. 135-154.

Schering A., "Die Lehre von den musikalischen Figuren im 17. und 18. Jahrhundert," Kirchenmusikalisches Jahrbuch 21 (1908), pp. 106-114.

Schweitzer A., J.S. Bach, transl. by E. Newman, New York 1966, vol. 2.

Speerstra J., Bach and the Pedal Clavichord: An Organist's Guide, Rochester 2004.

Spitta Ph., Joh. Seb. Bach, Leipzig 1916 [1873], Bd. 1.

Spitta Ph., Johann Sebastian Bach: His Work and Influence on the Music of Germany,

1685-1750, transl. by C. Bell, J.A. Fuller Maitland, London 1899 [1884], vol. 1.

Stinson R., Bach: The Orgelbüchlein, New York \& Oxford 1999 [1996].

Tarling J., The Weapons of Rhetoric: A Guide for Musicians and Audiences, St. Albans 2004.

Thomas W., “Zu Weisen und Texten,” in: J.S. Bach, Choralsätze zum Orgelbüchlein, hg. von H. Keller, Kassel 1969.

Unger H.-H., Die Beziehungen zwischen Musik und Rhetorik im 16.-18. Jahrhundert, Hildesheim 1985 [1941].

Walther J.G., Praecepta der musicalischen Composition, hg. von P. Benary, Leipzig 1955.

Williams P., The Organ Music of J.S. Bach, vol. 1-2, Cambridge 2008 [1 $1^{\text {st }}$ ed.: 1980, $2^{\text {nd }}$ ed., revised: 2003].

Williams P., The Organ Music of J.S. Bach: III A Background, Cambridge 1989 [1984].

Wilson B., Buelow G.J., Hoyt P.A., "Rhetoric and Music," in: The New Grove Dictionary of Music and Musicians, ed. by S. Sadie, London \& New York 2001, vol. 21, pp. 260-275.

www.bach-cantatas.com

www.bach-digital.de 